\title{
Post-Mortem Over Precautionary Principle: A Hazardous Policy
}

\section{S Jeevananda Reddy*}

Formerly Chief Technical Advisor - WMO/UN and Expert - FAO/UN and Fellow, Telangana Academy of Sciences [Founder Member] and Convenor, Forum for a Sustainable Environment, Hyderabad, Telangana, India

*Corresponding Author: S Jeevananda Reddy, Formerly Chief Technical Advisor - WMO/UN and Expert - FAO/UN and Fellow, Telangana Academy of Sciences [Founder Member] and Convenor, Forum for a Sustainable Environment, Hyderabad, Telangana, India.

Precautionary principle emphasises caution, which means prevention is better than cure or after burning of hands catching leaves serves little. Post-mortem is an analysis or discussion of an event after it is over. Here it is easy to put the blame on some others. We rarely learn from the past experiences. Indian politicians never cared to follow the precautionary principle but are looking at post-mortem, particularly on the impact of calamities such as cyclones, floods, pollution, etc. on agriculture or viruses like Covid-19. Let us see in brief the two prominent global disasters that affected humanity and economy along with two recent cases of local disasters.

\section{Global disaster of $60 \mathrm{~s}$}

Natural calamities are common around the globe. In agriculture to minimise the risk associated with climate related calamities our fore-fathers developed adaptive measures. Some such practices can be seen from Vedic literature in India and from local reports around the globe. Rigveda Hymns describe cultivation systems-water resources use existing in India. Also, there are several other inscriptions/excavations that showed the ancient agriculture practices. That the climate probably not the sole cause of Harappa decline. Despite the monsoon decline, the civilization did not disappear. The people changed their farming practices. They switched from water-intensive crops when monsoon was stronger to drought-resistant crops when it was weaker. These people shifted their crop patterns from the larger-grained cereals like wheat and barley during the early part of intensified monsoon to drought-resistant species of small millets and rice in the later part of declining monsoon, and thereby changed their subsistence strategy. To counter the negative impacts, people developed underground grain storage facilities, put in heaps after harvest to get correct time to separate grains to avoid damage due to unseasonal rains or some other calamity during the harvest time. Now we rarely practice them under the high inputs-subsidized new technology regimes.

All over the globe the negative impacts of chemical inputs agricultural technologies of 1960s have been experiencing and yet thrusting Genetically Modified seed technology that amplify the
Received: April 17, 2020

Published: April 20, 2020

(C) All rights are reserved by $\mathbf{S}$ Jeevananda Reddy. negative impacts. All these are activated under the disguise of food security. We must realize the fact that food security is not a function of quantity of food produced but it is a primary function of quality of food produced. Around 30 to $40 \%$ of food produced around the globe is going as waste along with the inputs used to produce that at huge government subsidy component. This technology introduced air, water, and land and food pollution and thus created innumerable health hazards. To serve this drug manufacturing industries and hospitals to treat them have been established, which in turn created different types of hazardous pollutions. The vicious circle is going round and round; thus it became a silent killer technology but people behind such technology were bestowed with awards and rewards. This would have been avoided if nations have followed precautionary principle while choosing the new technologies. Now governments are looking at post-mortem schemes at huge cost to act on pollution. We are experiencing the same scenario with IT based social networking, put the younger generation on danger zone.

Traditionally input and food subsidies were provided by central government. With the regional political parties' entry in a big way in to Indian political arena, agriculture became the scapegoat of vote bank politics. States introduced populistic schemes of subsidies over and above the central schemes instead of developing an agriculture system similar to the centuries old traditional system that affectively tackle the natural disaster menaces. This is not stopped here but the central government also started over playing the states on this. However, the states and central governments forgot the security against the natural calamities except looking at post-mortem.

\section{Global disaster of 2020s}

Timely action by central government should have contained or stopped the spread of Covid-19 in India and thus the national disaster in terms of economy and in terms of agriculture. Here the central government should have applied precautionary principle by not allowing thousands of people from India and abroad coming to attend Tablighi Jamaat meeting at Markaj Nizamuddin in Delhi when Delhi was facing riots on citizenship bill. Or at least the central government should have stopped the people in Markaj Niza- 
muddin leaving the building. In the case of two Telugu states the virus entered and spread from those people who came from Markaj Nizamuddin. However, in both the counts central government failed the rule of precautionary principle and now trying post-mortem action. By that time the national economy was in scramble and farmers suffered severe blow in the timely completing harvest and unfortunately at this time untimely rains affected the harvest also. The ruling party might have gained politically but failed miserably in running the nation.

Here the basic problem was the past and present government's policies of encouraging rural to urban migration to meet the real estate needs at the cost of agriculture in rural India faced severe return migration with Covid-19. The urban labour force created problems with migration back to their villages illegally. If agriculture becomes uneconomical, the small and marginal farmers and people depending upon agriculture tend to migrate to urban areas, more particularly to capital cities for greener pastures. Under the economic reforms more thrust is put on urban/capital cities in terms of developmental activities. With this scenario under Covid-19 both the rural and the urban areas are in deep crisis. Social networking-IT is in fact worse impact compared Covid-19 as it brought down drastically the effective work hours in all fields of work but the companies are minting trillions of dollars.

\section{Local-regional disasters}

Local-regional disasters are common every year. There are several government agencies to act in time to avoid them by applying precautionary principle. They are rarely implemented in true spirit and thus they preferred to go for post-mortem. Let us see few examples: (1) Bhopal Gas Tragedy: This happened at a Union Carbide subsidiary pesticide plant in the city of Bhopal in Madhya Pradesh on the night of 2 - 3 December 1984. The plant released approximately 40 tonnes of toxic methyl isocyanate (MIC) gas, exposing more than five lakh people to toxic gas. Here the local body violated by allowing people live around the factory in huge number against the statutory law. These are the people affected severely. (2) Reliance coal ash dam tragedy: A recent report states that "On April 10, 2020 evening, huge dam holding millions of litres of toxic and carcinogenic coal ash slurry breached and flowed down, killing people, destroying downstream rivers, fields and houses and ultimately ended up in the Rihand Dam Reservoir, polluting the reservoir and destroying its storage capacity. In a year, it is the third such incident. Here nobody dared to regulate the company. Even I myself noticed this. Gamana, an NGO invited me along with few other environmental activists to Kakinada. We visited Reliance project. I submitted a report to the state and central government agencies on the violation of environmental laws by RIL. This was published in The Hindu (24th September 2007) with the heading "Greens see red over Reliance project: RIL accused of closing creeks, uprooting mangroves for locating onshore gas, oil terminal" - Forest officials express helplessness; it is not just the question of losing mangroves and creeks but the livelihood of hundreds of fishermen.
Let us hope the governments give priority to "precautionary Principle" over "Post-mortem" to save people, to save environment and finally to save economy.

\section{Assets from publication with us}

- Prompt Acknowledgement after receiving the article

- Thorough Double blinded peer review

- Rapid Publication

- Issue of Publication Certificate

- High visibility of your Published work

Website: www.actascientific.com/

Submit Article: www.actascientific.com/submission.php Email us: editor@actascientific.com

Contact us: +919182824667 